\title{
TEACHER EDUCATION IN ENGLISH MEDIUM INSTRUCTION SETTINGS: A PARTIAL VIEW FROM BRAZIL
}

\author{
Telma Nunes Gimenez ${ }^{1 \times}$ \\ Marilice Zavagli Marson ${ }^{1 * *}$ \\ ${ }^{1}$ Universidade Estadual de Londrina, Londrina, PR, Brasil
}

\begin{abstract}
Research on English Medium Instruction (EMI) has increased around the world, especially in Europe and Southeast Asia (Macaro et al., 2018). In Brazil, studies have focused on the implementation of EMI in higher education institutions and ways of improving it (Baumvol \& Sarmento, 2019). This article analyzes EMI preparatory courses offered in Brazilian higher education institutions, according to publications from 2016 to 2020. To identify such courses, we conducted a search on Google and Google Scholar to map publications between 2016-2020. Through content analysis we conclude that initial efforts to prepare lecturers for EMI contexts present a great variety of purposes, duration and approaches, with many research gaps in need of further development.
\end{abstract}

Keywords: EMI; Teacher education; Brazilian higher education

"Senior Professor at the Postgraduate Program in Language Studies/Universidade Estadual de Londrina. Email: tgimenez@uel.br ORCID: https://orcid.org/0000-0001-6143-3895. The author expresses gratitude to CNPq for the support (Proc. 311655/2018-1).

${ }^{* *}$ Ph.D. candidate at the Postgraduate Program in Language Studies/Universidade Estadual de Londrina (UEL), Paraná, Brazil. Email: marilicemarson@gmail.com ORCID: https://orcid.org/0000-0001-9805-3001. 


\section{Introduction}

The continuing expansion of English Medium Instruction (EMI) offerings in higher education institutions around the world has spurred an increasing number of studies carried out by researchers in the field of Applied Linguistics. While a great deal of the studies focuses on policy issues (Galloway, 2020), research into implementation has been driven by an interest in working with teachers from different disciplinary areas who are in charge of transitioning to classes in English, in addition to or as a substitute for the home language of most students.

In an extensive review of international publications, Macaro et al. (2018) pointed out that a great number of those investigations addressed teachers' and students' beliefs and attitudes about EMI. One key assumption is that favorable attitudes would facilitate the implementation of classes in English, whereas a negative stance would hinder its development. Although attitudes do play an important role in teachers' willingness to teach in English in contexts where there is a more relaxed policy orientation, they are not enough to drive the transition to classes in English.

Considering that policy formulation, enactment and assessment are central to many institutions that view EMI as an important internationalization strategy (e.g. Aizawa \& Rose, 2019), the process of introducing classes in English to contexts where it is not the language of the majority requires the preparation of teachers, especially because this tends to be the first (and oftentimes, the only) initiative.

It is therefore surprising that Macaro et al. (2018, p. 56) could not identify research data in this area, stating that "pre-service programs do not exist, or researchers have not been interested in exploring them". It is reasonable to assume, though, that non-language teachers are receiving some kind of preparation, but researchers have directed their investigations into other issues, like perceptions, proficiency, motivations and challenges, as indicated in Galloway (2020).

Much like what is happening in many parts of the developing world, Brazilian higher education institutions have also started to open opportunities for classes to be taught in English (Baumvol \& Sarmento, 2016; Martinez, 2016, Gimenez et al., 2018;). One of the main initiatives has been to provide the non-language teachers some form of 'training', in order to help them cope with the demands of adjusting their teaching to this new situation. The professionals who have been frequently called upon to provide this type of preparation are language teachers, many of whom have been working in other internationalization strategies, such as equipping teachers and students to speak a foreign language, not to mention that many have become involved in activities developed by university international relations offices.

Partnerships between language specialists and lecturers from other disciplinary areas are not new in our country. The Brazilian ESP Project (Celani et al., 2009) for instance, was developed in the 1980s to help Brazilian teachers and students in higher education to read academic texts in English, in order to enable access to the knowledge disseminated in this language. While ESP and 
EAP approaches tended to concentrate on reading skills, the dynamics of the new context of academic exchanges requires the development of other language skills, purportedly enhanced by classes in English. In fact, this type of motivation has been one frequent one mentioned by policy-makers and lecturers, despite the fact that EMI does not aim at developing language skills (Galloway \& Rose, 2021).

Considering that internationalization efforts cannot ignore the need to address language development, it is not surprising that language teachers are called upon to play a major role in these initiatives. That has been the case of the program Languages without Borders (Sarmento et al., 2016) and Paraná Speaks Languages (Rios et al., 2021), both created to support internationalization of higher education in Brazil. In addition to being responsible for the practical implementation of language courses, teachers of English to speakers of other languages can also engage in research that can inform policy in EMI contexts (Pecorari \& Malmstrom, 2018).

While it is subject to debate whether EMI should avoid focusing on language in order to differentiate it from CLIL (e.g. Baumvol \& Sarmento, 2019), the decision to teach in English in Brazilian universities has been associated to the hope that both content and language will be developed, even if only through the exposure to the terminology or jargon of the area of study. The expectation that some language development will occur and the increasing presence of language specialists in internationalization initiatives has contributed to many ELT professionals being responsible for the preparation of non-language lecturers. This trend can be partially explained by the fact that many EMI classrooms present language-related challenges (Curle et al., 2020), and that prior foreign language teaching programs supported by the government to foster internationalization of higher education have been coordinated by language specialists, as mentioned earlier.

In order to understand recent initiatives to introduce EMI pedagogical strategies to non-language teachers, as well as to identify their objectives, approaches and outcomes, we analyze EMI preparatory courses offered in Brazilian higher education institutions, according to publications in the last five years (2016-2020). Although this overview is not exhaustive, it aims at giving visibility to these initiatives and at suggesting possible gaps that can be filled by additional research, in order to support teacher development programs that are in tune with the language issues involved in EMI delivery.

This study was guided by four main research questions:

1. What are the characteristics of EMI teacher education courses announced by universities in Brazil, in relation to facilitators, target audience, duration and mode of delivery?

2. According to published reports of EMI teacher education courses, who are the participants, what are the objectives, syllabi, and methodologies? 
3. What are the most explored aspects in the professional development of EMI lecturers considering those reports? What do they indicate?

4. What are the possible research gaps in EMI teacher education in Brazil?

\section{Teacher education for EMI teaching}

In recent years, we have witnessed the growth of research on EMI both internationally and in Brazil (Gimenez et al., 2021). Although EMI has been discussed in many parts of the world, more substantially in Europe and Southeast Asia, little is known about teacher education (or training) and EMI pedagogy, especially in South America (Martinez \& Fernandes, 2020) and in Brazil (Pusey, 2020a; 2020b). However, given the increasing number of EMI courses in Brazilian higher education institutions (Gimenez et al., 2018), it is reasonable to assume that some kind of support is being offered to lecturers.

There are many challenges associated with teaching in a foreign language, including those related to proficiency, self-confidence, and pedagogy (Martinez \& Fernandes, 2020). Other issues are equally important such as the consequences of educating professionals and researchers in a language of global significance and thus reinforcing its hegemonic status (Jordão, 2016).

Given the centrality of language in those challenges, concerns over proficiency, i.e. inadequate levels of English by both teachers and students are common (Macaro et al., 2019). There is widespread fear that diminished learning outcomes will result from teachers and learners trying to engage with knowledge building through a medium they are not confident about. However, it might be important to reflect on the rationales of such practice, usually associated with internationalization efforts. As Knight (2021) points out:

rationales are reflected in the policies and programs that are developed and eventually implemented. Rationales dictate the kind of benefits or expected outcomes. Without a clear set of rationales, accompanied by a set of objectives or policy statements, an implementation plan, and a monitoring/evaluation system; the process of internationalization is often an $a d h o c$, reactive, and fragmented response to the overwhelming number of new international opportunities available. (Knight, 2021, pp. 75)

Motivations to introduce classes in English when the majority of the students share a common language include the desire to be seen as an international university', mimicking some of the practices adopted by higher education institutions in other countries, among which teaching in English takes center stage. This trend is not without critics, as Martinez (2016) remarks that "Brazil is not Europe". He adds: "[...] internationalization can bring many interesting benefits, but preoccupation with internationalizing -- through English -- in 
order to compete with other universities is what has led to EMI failure in other contexts." (Martinez, 2016, pp. 22).

The author believes that "EMI alone should not be counted on to increase internationalization" (Martinez, 2016, p. 10), since a long-term strategic planning in this regard does not seem to be taken into consideration, specially on teacher development. For this reason, EMI turns into "a kind of internationalization window dressing" (Martinez, 2016, p. 18). Although EMI cannot be synonymous with internationalization, it has been considered a proxy for that process, helping spread the idea that internationalization means Englishization (Wilkinson \& Gabriëls, 2021).

Success in EMI implementation seems to be driving most of the current research in EMI, with the identification of potential factors that can enhance classroom practices. Among those, teachers' abilities to teach through the medium of English needs to go beyond their own proficiency, to consider the reconstruction of their professional knowledge base and to expand their pedagogical content knowledge. In other words, being an EMI teacher does not depend only on attitudes (although they need to be a starting point), but also on reframing their roles in a changing educational environment. As a result of the interest in developing teachers' competencies, and with an eye to quality assurance, many organizations are starting to offer online courses and even providing certification. One of such organizations is the prestigious Cambridge Assessment, that offers the Certificate in EMI Skills, a 40-hour online course. It is directed to "university professors, lecturers, tutors and researchers whose first language is not English, but who use English to teach students, present academic papers and interact with colleagues". Other Anglophone sources are also offering short-term online courses aimed at a larger audience, such as the University of Southampton and Future Learn (Macaro et. al. 2019). In addition to direct placement in the 'new market', these providers outsource to local counterparts, like the case of Seven Idiomas, with its Brazilian teaching staff for the Cambridge course.

It is perhaps ironic that those who present themselves with the expertise to be shared with teachers around the world are the ones who do not necessarily experience EMI teaching, as defined by Dearden $(2015)^{2}$, for instance. The wide acceptance of these credentials may reside in the fact that these are organizations with large experience in language teaching, and if EMI involves basically the need to include the 'language factor' into teaching, it would be natural to have them as course designers and implementers. Here, it seems that ideologies of native speakerism may be playing a part, although not explicitly, as Britishness may function as a surrogate of quality.

In addition to these external course providers, higher education institutions have also been organizing their own professional development opportunities, some of which rely on external expertise, as we will discuss later. Those who seek to establish an international standard for EMI teaching see the multiplicity of objectives, duration, methodologies and formats a situation to be remedied by achieving a consensus of what EMI teachers' competencies might look like. 
However, as we are still in the infancy of describing the different contexts for EMI delivery, it may be a while before a consensus is reached. More importantly, it is questionable whether there should be international standards and certifying bodies involved in a practice that is bound to be locally reinterpreted (Pecorari \& Malmstrom, 2018). Important questions about this move would involve uncovering whose interests would be served by such a project.

\section{Method}

In order to identify courses offered by higher education institutions to support EMI teaching in Brazil, we carried out a search on Google with the term "EMI preparation courses", on April 10, 2021. Seven (7) references were found through announcements and university news bulletins. Additionally, Google Scholar was used to map publications between 2016-2020, with six (6) references found.

The first and second sets of texts (announcements, news and academic publications) were scrutinized via content analysis to identify: source, institution, facilitator(s), title of the course, audience, duration, and mode of delivery. Doublechecking was carried out separately by the authors.

Content analysis was used in this article considering that it is "a method for systematically describing the meaning of qualitative material. It is done by classifying material as instances of the categories of a coding frame" (Schreier, 2012, p. 1).

\section{Findings}

We approached the question about the universities offering EMI teacher preparation courses and the basic characteristics of those courses by summarizing the data found through the Google search in Tables 1 and 2.

Table 1 - EMI teacher education courses offered in Brazil: university news bulletins captured on a Google search

\begin{tabular}{|c|c|c|c|c|c|}
\hline Institution/Source & Facilitator(s) & Title & $\begin{array}{l}\text { Target } \\
\text { audience }\end{array}$ & Year/Duration & Mode \\
\hline $\begin{array}{l}\text { UFMG University } \\
\text { news bulletin. } \\
\text { https://www.ufmg. } \\
\text { br/dri/curso-de- } \\
\text { ingles-como-meio-de- } \\
\text { instrucao-emi-para- } \\
\text { docentes-e-discentes- } \\
\text { da-pos-graduacao- } \\
\text { stricto-sensu/ }\end{array}$ & $\begin{array}{l}\text { University of } \\
\text { Southampton, } \\
\text { through the } \\
\text { International } \\
\text { Relations Office } \\
\text { and PosLin (FALE, } \\
\text { in Portuguese } \\
\text { acronym). }\end{array}$ & $\begin{array}{l}\text { English as a } \\
\text { medium of } \\
\text { instruction - } \\
\text { EMI. }\end{array}$ & $\begin{array}{l}\text { Postgraduate } \\
\text { students and } \\
\text { teachers interested } \\
\text { in academic classes } \\
\text { in English. UFMG } \\
\text { teachers and staff } \\
\text { involved with } \\
\text { internationalization. }\end{array}$ & 2020 (4 weeks). & $\begin{array}{l}\text { Online } \\
\text { (MOOC). }\end{array}$ \\
\hline
\end{tabular}




\begin{tabular}{|c|c|c|c|c|c|}
\hline $\begin{array}{l}\text { PUCPR University } \\
\text { news bulletin. } \\
\text { https://www.pucpr.br/ } \\
\text { international/news/ } \\
\text { english-as-a-medium- } \\
\underline{\text { of-instruction-emi- }} \\
\underline{\text { classes-have-just- }} \\
\underline{\text { started/ }}\end{array}$ & $\begin{array}{l}\text { PUCPR (offered } \\
\text { by the Humanities } \\
\text { and Education } \\
\text { Center by teacher } \\
\text { Karina Fernandes). }\end{array}$ & $\begin{array}{l}\text { Inglês como } \\
\text { Meio de } \\
\text { Instrução } \\
\text { (English as a } \\
\text { Medium of } \\
\text { Instruction } \\
\text { - EMI) na } \\
\text { PUCPR. }\end{array}$ & $\begin{array}{l}\text { Teachers, deans and } \\
\text { internationalization } \\
\text { agents. }\end{array}$ & $\begin{array}{l}2019 \text { (no } \\
\text { information } \\
\text { available about } \\
\text { duration). }\end{array}$ & $\begin{array}{l}\text { Face-to- } \\
\text { face. }\end{array}$ \\
\hline $\begin{array}{l}\text { UFMS University } \\
\text { news bulletin. } \\
\text { https://www.ufms.br/ } \\
\text { docentes-participam- } \\
\text { de-curso-emi-em- } \\
\text { campo-grande/ } \\
\text { https://www.ufms. } \\
\text { br/aginova-inicia- } \\
\text { terceira-turma-do- } \\
\text { curso-de-capacitacao- } \\
\text { emi/ }\end{array}$ & $\begin{array}{l}\text { UFMS Campo } \\
\text { Grande (by Simone } \\
\text { Sarmento and } \\
\text { Leandro Kessler). }\end{array}$ & $\begin{array}{l}\text { English as a } \\
\text { Medium of } \\
\text { Instruction } \\
\text { (EMI). }\end{array}$ & UFMS teachers. & $\begin{array}{l}2019 \text { (the last } \\
\text { edition was in } \\
\text { February 2020). }\end{array}$ & $\begin{array}{l}\text { Face-to- } \\
\text { face. }\end{array}$ \\
\hline $\begin{array}{l}\text { UFRJ University news } \\
\text { bulletin. } \\
\text { https://isf.letras.ufrj. } \\
\text { br/2018/10/18/fotos- } \\
\text { do-emi-workshop/ }\end{array}$ & $\begin{array}{l}\text { UFRJ (by Simone } \\
\text { Sarmento in a } \\
\text { partnership with } \\
\text { the International } \\
\text { Relations Office } \\
\text { and Professor } \\
\text { Christine } \\
\text { Nicolaides, } \\
\text { the Language } \\
\text { without Borders } \\
\text { Program general } \\
\text { coordinator at } \\
\text { UFRJ). }\end{array}$ & $\begin{array}{l}\text { EMI } \\
\text { Workshop } \\
\text { (English as } \\
\text { Medium of } \\
\text { Instruction } \\
\text { ou Inglês } \\
\text { como Meio de } \\
\text { Instrução). }\end{array}$ & $\begin{array}{l}\text { IsF (Languages } \\
\text { without Borders) } \\
\text { teachers from UFRJ. }\end{array}$ & 2018 (2 days). & $\begin{array}{l}\text { Face-to- } \\
\text { face. }\end{array}$ \\
\hline $\begin{array}{l}\text { UNICENTRO } \\
\text { University news } \\
\text { bulletin. } \\
\text { https://www3. } \\
\text { unicentro.br/eventos/ } \\
\text { emi/ }\end{array}$ & Unicentro (by PFI). & $\begin{array}{l}\text { EMI - English } \\
\text { as a Medium } \\
\text { of Instruction } \\
\text { - Paraná Fala } \\
\text { Inglês. }\end{array}$ & $\begin{array}{l}\text { Unicentro teachers } \\
\text { interested in teaching } \\
\text { their academic } \\
\text { subjects in English. }\end{array}$ & $\begin{array}{l}2019 \text { ( } 60 \text { hours of } \\
\text { duration). }\end{array}$ & $\begin{array}{l}\text { Face-to- } \\
\text { face and } \\
\text { online. }\end{array}$ \\
\hline $\begin{array}{l}\text { UFPR } \\
\text { University news } \\
\text { bulletin. } \\
\text { https://uenp. } \\
\text { edu.br/noticias/ } \\
\text { item/2388-docentes- } \\
\text { das-universidades- } \\
\text { estaduais-participam- } \\
\text { de-capacitacao-para- } \\
\text { lecionar-em-ingles }\end{array}$ & $\begin{array}{l}\text { UFPR in a } \\
\text { partnership with } \\
\text { the seven state } \\
\text { universities of } \\
\text { Paraná. }\end{array}$ & $\begin{array}{l}\text { Metodologia } \\
\text { de Educação } \\
\text { Superior: } \\
\text { Inglês como } \\
\text { Meio de } \\
\text { Instrução. }\end{array}$ & $\begin{array}{l}\text { Teachers from } \\
\text { different regions of } \\
\text { Paraná to teach in } \\
\text { English. }\end{array}$ & $\begin{array}{l}2018 \text { and } 2019 \text { (60 } \\
\text { hours). }\end{array}$ & $\begin{array}{l}\text { Face-to- } \\
\text { face. }\end{array}$ \\
\hline
\end{tabular}




\begin{tabular}{|c|c|c|c|c|c|}
\hline $\begin{array}{l}\text { UNIVERSITIES IN } \\
\text { PARANÁ. } \\
\text { University news } \\
\text { bulletin. } \\
\text { https://operobal.uel.br/ } \\
\text { educacao/2020/10/05/ } \\
\text { embaixadadoseuaeuel/ }\end{array}$ & $\begin{array}{l}\text { Christopher } \\
\text { Stillwell, Professor } \\
\text { of English as a } \\
\text { Second Language } \\
\text { at the University of } \\
\text { California, Irvine, } \\
\text { CA. }\end{array}$ & EMI in Paraná. & $\begin{array}{l}\text { Postgraduate teachers } \\
\text { who teach or intend } \\
\text { to teach academic } \\
\text { subjects in English } \\
\text { (English as a Medium } \\
\text { of Instruction - EMI). }\end{array}$ & 2020 (15 hours). & Online. \\
\hline
\end{tabular}

Note. The authors based on a Google search on April 10, 2021

Table 2 - EMI teacher education courses offered in Brazil: academic texts

\begin{tabular}{|c|c|c|c|c|c|}
\hline Authors & Facilitators & $\begin{array}{l}\text { Title of the } \\
\text { courses offered }\end{array}$ & Target audience & Year/duration & Mode \\
\hline $\begin{array}{l}\text { Jordão } \\
\text { (2016). }\end{array}$ & $\begin{array}{l}\text { Universidade Federal } \\
\text { do Paraná (UFPR), as } \\
\text { an initiative by Clarissa } \\
\text { Menezes Jordão, professor } \\
\text { at the institution, and } \\
\text { an English teacher from } \\
\text { Poland. }\end{array}$ & $\begin{array}{l}\text { English for } \\
\text { Internationalization. }\end{array}$ & $\begin{array}{l}\text { Experienced } \\
\text { professors/ researchers } \\
\text { whose contact with the } \\
\text { English language was } \\
\text { already part of their } \\
\text { professional routine } \\
\text { (i.e. international } \\
\text { publications } \\
\text { and conference } \\
\text { presentations in } \\
\text { English). }\end{array}$ & (2015) 40 hours. & $\begin{array}{l}\text { Face-to- } \\
\text { face. }\end{array}$ \\
\hline $\begin{array}{l}\text { Verdu } \\
\text { (2017). }\end{array}$ & $\begin{array}{l}\text { Universidade Estadual de } \\
\text { Maringá (UEM), by the } \\
\text { International Cooperation } \\
\text { Office and the Post- } \\
\text { graduation Program in } \\
\text { Administration. }\end{array}$ & $\begin{array}{l}\text { English as a } \\
\text { Medium of } \\
\text { Instruction (EMI). }\end{array}$ & $\begin{array}{l}\text { All the students and } \\
\text { teachers interested. }\end{array}$ & 2016 (20 hours). & $\begin{array}{l}\text { Face-to- } \\
\text { face. }\end{array}$ \\
\hline $\begin{array}{l}\text { Rodrigues } \\
\text { \& Rocha } \\
\text { (2020). }\end{array}$ & $\begin{array}{l}\text { Universidade Federal do } \\
\text { Piauí (UFPI). Research } \\
\text { group (professors, } \\
\text { graduate students, ETAs) } \\
+3 \text { university professors } \\
\text { leading sessions. }\end{array}$ & $\begin{array}{l}\text { Continuous } \\
\text { education on } \\
\text { English as a } \\
\text { Medium of } \\
\text { Instruction - EMI. }\end{array}$ & $\begin{array}{l}\text { Post-graduation } \\
\text { professors. }\end{array}$ & $\begin{array}{l}2019 \text { ( } 10 \text { weekly } \\
\text { meetings). }\end{array}$ & $\begin{array}{l}\text { No } \\
\text { information } \\
\text { available } \\
\text { about mode. }\end{array}$ \\
\hline $\begin{array}{l}\text { Züge, } \\
\text { Barreto } \\
\text { \& Novelli } \\
(2020) \text {. }\end{array}$ & $\begin{array}{l}\text { Universidade Estadual de } \\
\text { Maringá (UEM). } \\
\text { Teachers connected } \\
\text { to the institution's PFI } \\
\text { (a language instructor } \\
\text { and the pedagogical } \\
\text { advisor); the program's } \\
\text { institutional coordinator } \\
\text { and the advisor from } \\
\text { the university's Office of } \\
\text { International Cooperation } \\
\text { also participated. }\end{array}$ & $\begin{array}{l}\text { Parana Speaks } \\
\text { Languages/English } \\
\text { Program - EMI. }\end{array}$ & $\begin{array}{l}\text { Undergraduate } \\
\text { and postgraduate } \\
\text { professors. }\end{array}$ & $\begin{array}{l}2019 \text { ( } 16 \text { hours, } \\
\text { in two phases). }\end{array}$ & $\begin{array}{l}\text { No } \\
\text { information } \\
\text { available } \\
\text { about mode. }\end{array}$ \\
\hline
\end{tabular}




\begin{tabular}{|c|c|c|c|c|c|}
\hline \multirow{2}{*}{$\begin{array}{l}\text { Martinez } \\
\& \\
\text { Fernandes } \\
(2020)\end{array}$} & $\begin{array}{l}\text { Universidade Federal } \\
\text { do Paraná (UFPR) in } \\
\text { a partnership with the } \\
\text { Oxford University. }\end{array}$ & $\begin{array}{l}\text { EMI Oxford } \\
\text { Research Group. }\end{array}$ & UFPR professors. & 2016 (35 hours). & $\begin{array}{l}\text { Face-to- } \\
\text { face. }\end{array}$ \\
\hline & $\begin{array}{l}\text { Oxford EMI Group } \\
\text { Julie Dearden and Tom } \\
\text { Spain + Ron Martinez, } \\
\text { Karina Fernandes (with } \\
\text { a focus on a doctoral } \\
\text { dissertation). }\end{array}$ & EMI UFPR Course. & UFPR professors. & 2018 (35 hours) & $\begin{array}{l}\text { Face-to- } \\
\text { face. }\end{array}$ \\
\hline $\begin{array}{l}\text { Pusey } \\
(2020 a) .\end{array}$ & $\begin{array}{l}\text { UNISINOS, by Kerry } \\
\text { Pusey, a visiting professor } \\
\text { from the University of } \\
\text { Pennsylvania (UPenn), } \\
\text { Philadelphia, PA, United } \\
\text { States. }\end{array}$ & $\begin{array}{l}\text { EMI support } \\
\text { courses. }\end{array}$ & $\begin{array}{l}\text { To help UNISINOS } \\
\text { faculty for linguistic } \\
\text { and pedagogical } \\
\text { challenges associated } \\
\text { with EMI. Also, it } \\
\text { was designed to raise } \\
\text { faculty awareness } \\
\text { of the many issues } \\
\text { (i.e., educational, } \\
\text { sociological, cultural, } \\
\text { political) involved in } \\
\text { EMI implementation. }\end{array}$ & $\begin{array}{l}2019 \text { ( } 48 \text { contact } \\
\text { hours with } \\
\text { meetings held } \\
\text { bi-weekly over } \\
\text { two semesters). }\end{array}$ & $\begin{array}{l}\text { Face-to- } \\
\text { face. }\end{array}$ \\
\hline
\end{tabular}

Note. The authors based on a Google search on April 10, 2021

This brief and not exhaustive list reveals that federal, state and not for profit universities located mainly in the South-Southeast of Brazil were offering teacher education courses in EMI: UFPI, UFMG, PUCPR, UFRJ, UFMS, UFPR, UNICENTRO, UEM, and UNISINOS, in addition to other state universities in Paraná. While some of them are being funded by the CAPES-PrInt program (UFMG, UFRJ, UFMS, UFPR and UNISINOS), others are not, something that may reveal different motivations to introduce EMI.

In relation to the facilitators, some dependence on external expertise was identified by the invitation to foreign and local experts based in other universities. This can be interpreted as adherence to ideologies related to native speakerism or absence of local expertise to design and implement those courses.

Considering that EMI is being introduced mainly in postgraduate courses (Gimenez et al., 2018), it is understandable that the preferred target group was professors working at that level. The configuration of those courses that had a mix of teachers, students and even administrative staff may have been different from those aimed only at teachers, which clearly focus on teaching only. One can speculate that this reveals an intention of having EMI as a format for English language teaching.

The duration of those courses varied tremendously, from 15 to 60 hours, with both face-to-face and online activities, attesting the diversity of depth in which the course contents were approached. In order to have a closer look at what happened in those courses, we discuss more 
detailed information about them next. Table 3 brings a summary of the course participants, objectives, syllabus and methodology, verbatim.

Table 3 - Summary of Brazilian teacher education courses for EMI

\begin{tabular}{|c|c|c|c|c|}
\hline Institutions/Publications & $\begin{array}{l}\text { Participants } \\
\text { (registration/ } \\
\text { completion) }\end{array}$ & Objectives & Syllabus & Methodology \\
\hline $\begin{array}{l}\text { UFPI (Rodrigues \& Rocha, } \\
2020 .\end{array}$ & $\begin{array}{l}8 \text { professors } \\
\text { from UFPI and } \\
2 \text { from UESPI. } \\
6 \text { attended the } \\
\text { course and } 4 \\
\text { completed the } \\
\text { final task. }\end{array}$ & $\begin{array}{l}\text { To help professors } \\
\text { from post- } \\
\text { graduation } \\
\text { programs from } \\
\text { UFPI who were } \\
\text { interested in } \\
\text { learning about } \\
\text { how to teach } \\
\text { using English } \\
\text { as a Medium of } \\
\text { Instruction to be } \\
\text { able, subsequently, } \\
\text { to develop a course } \\
\text { or a seminar } \\
\text { to be taught in } \\
\text { English in their } \\
\text { post-graduation } \\
\text { programs. The } \\
\text { main objective was } \\
\text { to help them to } \\
\text { develop the skills } \\
\text { they needed to feel } \\
\text { more comfortable } \\
\text { in performing } \\
\text { academic activities } \\
\text { in English. }\end{array}$ & $\begin{array}{l}\text { EMI, definition } \\
\text { and presentation; } \\
\text { Using English } \\
\text { in international } \\
\text { contexts; Intercultural } \\
\text { competences; CLIL } \\
\text { X EMI; Assessment } \\
\text { in English in EMI } \\
\text { contexts; English } \\
\text { imperialism X } \\
\text { multilingual } \\
\text { empowerment: } \\
\text { teaching without } \\
\text { perpetuating cultural } \\
\text { bias; Andragogy; } \\
\text { Reviewing common } \\
\text { challenges in English } \\
\text { pronunciation; } \\
\text { Oral presentations } \\
\text { and speaking } \\
\text { activities; and Body } \\
\text { language: nonverbal } \\
\text { communication. }\end{array}$ & $\begin{array}{l}\text { Every week, the } \\
\text { participants received, } \\
\text { through email, some } \\
\text { materials about the } \\
\text { topic that would be } \\
\text { discussed in the next } \\
\text { session. They were } \\
\text { sent written authentic } \\
\text { texts (which were short } \\
\text { essays or papers that } \\
\text { were selected by the } \\
\text { group that planned } \\
\text { the course after some } \\
\text { discussions), and } \\
\text { sometimes videos } \\
\text { (selected from YouTube } \\
\text { or TED). On the emails, } \\
\text { which were sent by } \\
\text { the person who would } \\
\text { lead the next session, } \\
\text { besides talking a little } \\
\text { about the next topic, } \\
\text { there were also some } \\
\text { motivating words, } \\
\text { inviting the participants } \\
\text { to be present and to } \\
\text { read the texts and watch } \\
\text { the videos (when there } \\
\text { were any) in order to be } \\
\text { prepared to participate } \\
\text { more effectively in the } \\
\text { discussions that would } \\
\text { occur. }\end{array}$ \\
\hline $\begin{array}{l}\text { UEM-A (Züge, Barreto \& } \\
\text { Novelli, 2020). }\end{array}$ & $\begin{array}{l}31 \text { registers. First } \\
\text { phase }(8 \mathrm{~h})-5 \\
\text { took part. Second } \\
\text { phase }(8 \mathrm{~h})-4 \\
\text { took part. }\end{array}$ & $\begin{array}{l}\text { To fulfill the } \\
\text { commitment made } \\
\text { in } 2019 \text { to offer } \\
\text { a course on EMI } \\
\text { (representative took } \\
\text { the course at UFPR } \\
\text { and had to replicate } \\
\text { experience in his } \\
\text { institution). }\end{array}$ & $\begin{array}{l}\text { Basic notions about } \\
\text { the teaching and } \\
\text { learning processes } \\
\text { through LI in the } \\
\text { university context } \\
\text { (undergraduate } \\
\text { and graduate } \\
\text { courses), focusing } \\
\text { on methodological } \\
\text { possibilities to be } \\
\text { developed by teachers } \\
\text { in their classes. }\end{array}$ & $\begin{array}{l}\text { Expository module } \\
\text { (EMI concepts). } \\
\text { Practical module - } \\
\text { participants had to } \\
\text { present a lesson with } \\
\text { content from their } \\
\text { university subjects, } \\
\text { using LI and the } \\
\text { methodological } \\
\text { proposals presented in } \\
\text { the first module of the } \\
\text { course. }\end{array}$ \\
\hline
\end{tabular}




\begin{tabular}{|c|c|c|c|c|}
\hline & & & & $\begin{array}{l}\text { Feedback sessions - } \\
\text { through which each } \\
\text { participant could } \\
\text { receive an evaluation of } \\
\text { his or her performance } \\
\text { in the lesson } \\
\text { presentation, both } \\
\text { from the other course } \\
\text { participants and from } \\
\text { the teachers. }\end{array}$ \\
\hline UEM-B (Verdu, 2017). & $\begin{array}{l}20 \text { registered } \\
\text { (professors and } \\
\text { students), } 3 \text { of } \\
\text { them completed } \\
\text { the course } \\
\text { (only graduate } \\
\text { professors). }\end{array}$ & $\begin{array}{l}\text { To strengthen } \\
\text { Internationalization } \\
\text { at Home process at } \\
\text { UEM. }\end{array}$ & $\begin{array}{l}\text { It was a free course } \\
\text { taught in English } \\
\text { concerning EMI } \\
\text { aspects with a focus } \\
\text { on the development } \\
\text { of internationalization } \\
\text { at home at the Post- } \\
\text { graduation Program } \\
\text { in Administration at } \\
\text { UEM. }\end{array}$ & $\begin{array}{l}\text { There is no explicit } \\
\text { information about } \\
\text { the methodology, } \\
\text { however the professors } \\
\text { who completed the } \\
\text { course about EMI were } \\
\text { supposed to continue } \\
\text { publishing articles and } \\
\text { teaching in English as } \\
\text { a way to improve the } \\
\text { internationalization at } \\
\text { home process in the } \\
\text { university. }\end{array}$ \\
\hline UFPR - A (Jordão, 2016). & $\begin{array}{l}20 \text { enrolled, } \\
\text { less than half } \\
\text { completed the } \\
\text { course. }\end{array}$ & $\begin{array}{l}\text { Not to teach } \\
\text { English, but to use } \\
\text { English to discuss } \\
\text { academic actions, } \\
\text { such as presenting } \\
\text { papers, emails with } \\
\text { potential partners, } \\
\text { and planning and } \\
\text { implementing } \\
\text { classes in English } \\
\text { for Brazilian and } \\
\text { foreign students. The } \\
\text { goal was to critically } \\
\text { reflect on the need } \\
\text { and impact of using } \\
\text { English in academic } \\
\text { activities. }\end{array}$ & $\begin{array}{l}\text { Native speakerism. } \\
\text { Linguistic } \\
\text { imperialism, } \\
\text { (de)coloniality, } \\
\text { postmodernism. } \\
\text { Not a pre-planned } \\
\text { course with an } \\
\text { already established } \\
\text { syllabus, nor } \\
\text { English classes } \\
\text { as traditionally } \\
\text { understood, but } \\
\text { discussions and } \\
\text { activities around } \\
\text { academic actions, } \\
\text { developed in English } \\
\text { from the experiences } \\
\text { of participants } \\
\text { as researchers } \\
\text { in international } \\
\text { environments. } \\
\text { The aim was to create } \\
\text { a routine (culture) } \\
\text { of discussion and } \\
\text { academic production } \\
\text { in the English } \\
\text { language, }\end{array}$ & $\begin{array}{l}\text { The administration } \\
\text { embraced this } \\
\text { proposal and the } 40 \text { - } \\
\text { hour course started } \\
\text { in April 2015, with } \\
\text { the explicit intention } \\
\text { of becoming a site } \\
\text { for future research } \\
\text { - and for this I had } \\
\text { the collaboration of a } \\
\text { fellow professor from } \\
\text { Languages. She took } \\
\text { the responsibility of } \\
\text { taking ethnographic } \\
\text { notes of our meetings } \\
\text { and giving me } \\
\text { suggestions for class } \\
\text { planning, occasionally } \\
\text { stepping in for some } \\
\text { of the time. Before she } \\
\text { could join us, though, } \\
\text { our first meetings } \\
\text { were used to clarify } \\
\text { the course design, its } \\
\text { aims and intended } \\
\text { participants, as well as } \\
\text { to do some prospective } \\
\text { diagnosis of the group } \\
\text { in terms of their }\end{array}$ \\
\hline
\end{tabular}




\begin{tabular}{|c|c|c|c|c|}
\hline & & & $\begin{array}{l}\text { thus preparing } \\
\text { the university } \\
\text { structure for } \\
\text { internationalization. }\end{array}$ & $\begin{array}{l}\text { experience with the } \\
\text { English language. We } \\
\text { discussed especially } \\
\text { what we understood } \\
\text { by the reference to a } \\
\text { collaborative course } \\
\text { syllabus. }\end{array}$ \\
\hline $\begin{array}{l}\text { UFPR - B (Oxford) } \\
\text { (Martinez \& Fernandes, } \\
\text { 2020). }\end{array}$ & $\begin{array}{l}18 \text { graduate } \\
\text { professors. }\end{array}$ & $\begin{array}{l}\text { Main expected an } \\
\text { overall goal of the } \\
\text { Oxford EMI course } \\
\text { was to help lecturers } \\
\text { feel more confident } \\
\text { about delivering } \\
\text { their course(s) } \\
\text { through English. }\end{array}$ & $\begin{array}{l}\text { Language awareness. } \\
\text { Classroom dynamics. } \\
\text { Teacher-student } \\
\text { interaction. Observed } \\
\text { teaching practice. }\end{array}$ & $\begin{array}{l}\text { Essentially the same } \\
\text { course the Oxford } \\
\text { trainers delivered } \\
\text { to lecturers from } \\
\text { anywhere around the } \\
\text { world, irrespective of } \\
\text { culture and nationality. }\end{array}$ \\
\hline $\begin{array}{l}\text { UFPR - C } \\
\text { (Martinez \& Fernandes, } \\
\text { 2020, local pilot course). }\end{array}$ & $\begin{array}{l}23 \text { graduate } \\
\text { professors. }\end{array}$ & $\begin{array}{l}\text { First step in an } \\
\text { iterative process } \\
\text { of ongoing course } \\
\text { development, the } \\
\text { main expected } \\
\text { overall goal of the } \\
\text { Oxford EMI course } \\
\text { was to help lecturers } \\
\text { feel more confident } \\
\text { about delivering } \\
\text { their course(s) } \\
\text { through English. } \\
\text { Awareness of how } \\
\text { course content and } \\
\text { teaching dynamics } \\
\text { ultimately matter } \\
\text { more to students } \\
\text { than accent or } \\
\text { occasional lecturer } \\
\text { disfluencies. } \\
\text { How to plan and } \\
\text { deliver a class that } \\
\text { incorporates active } \\
\text { methodologies. Basic } \\
\text { techniques to signal } \\
\text { important points and } \\
\text { transitions in their } \\
\text { lessons. Awareness } \\
\text { of how to deal with } \\
\text { English language } \\
\text { errors in class. }\end{array}$ & $\begin{array}{l}\text { See Table } 1 . \\
\text { Developed from the } \\
\text { participation at the } \\
\text { Oxford EMI course } \\
\text { and an interview } \\
\text { with } 3 \text { other } \\
\text { participants. }\end{array}$ & $\begin{array}{l}\text { Activities were } \\
\text { student-led, requiring } \\
\text { participants to make } \\
\text { posters, for example, } \\
\text { or place self-adhesive } \\
\text { sheets of paper ("Post- } \\
\text { Its"). Several different } \\
\text { topics were focused on } \\
\text { throughout the course, } \\
\text { including discussion } \\
\text { of institutional } \\
\text { challenges, effective } \\
\text { teaching practices, } \\
\text { non-native speaker } \\
\text { identity. Classroom } \\
\text { management, active } \\
\text { methodologies, and so } \\
\text { on. The final assessment } \\
\text { was to be the delivery of } \\
\text { a twenty-minute class, } \\
\text { taught to their own } \\
\text { peers in the classroom. }\end{array}$ \\
\hline $\begin{array}{l}\text { UFPR - D } \\
\text { An intensive course. }\end{array}$ & 20 professors. & Same pilot course. & $\begin{array}{l}\text { Basically the same } \\
\text { pilot course, but with } \\
\text { fewer out-of-class } \\
\text { activities. Discussion } \\
\text { about language and } \\
\text { institutional policy. } \\
\text { Correction, language }\end{array}$ & \\
\hline
\end{tabular}




\begin{tabular}{|c|c|c|c|c|}
\hline & & & $\begin{array}{l}\text { from the student's } \\
\text { perspective (what } \\
\text { kind of proficiency } \\
\text { is required from the } \\
\text { student?, how students } \\
\text { should be evaluated } \\
\text { and to what extent } \\
\text { languages should be } \\
\text { only in English). }\end{array}$ & \\
\hline $\begin{array}{l}\text { UNISINOS (Pusey, } \\
\text { 2020a). }\end{array}$ & $\begin{array}{l}\text { Initially a total of } \\
25 \text { participants, } \\
\text { but due to various } \\
\text { scheduling } \\
\text { conflicts, only } 10 \\
\text { faculty members } \\
\text { completed the } \\
\text { entire course. }\end{array}$ & $\begin{array}{l}\text { To develop } \\
\text { teachers' knowledge } \\
\text { of language, } \\
\text { communication, } \\
\text { and pedagogy } \\
\text { for EMI, as well } \\
\text { as to raise their } \\
\text { awareness of } \\
\text { historical and } \\
\text { contemporary } \\
\text { issues (i.e., } \\
\text { challenges, policies, } \\
\text { relative advantages } \\
\text { and disadvantages) } \\
\text { connected to EMI } \\
\text { implementation. }\end{array}$ & $\begin{array}{l}\text { Educational, } \\
\text { sociological, cultural } \\
\text { and political issues } \\
\text { involved in EMI } \\
\text { implementation. }\end{array}$ & $\begin{array}{l}\text { The course culminated } \\
\text { with a curriculum } \\
\text { development project, } \\
\text { which required the } \\
\text { faculty participants to } \\
\text { create and formally } \\
\text { present an EMI course } \\
\text { proposal to the class, } \\
\text { with the hope that } \\
\text { these proposals could } \\
\text { actually be used in the } \\
\text { future. (Most of the } \\
\text { faculty members were } \\
\text { not currently teaching } \\
\text { EMI courses.) }\end{array}$ \\
\hline
\end{tabular}

Note. The authors based on academic texts found on a Google Scholar search on April 10,2021

The average of 20 participants appeared to be an adequate number in face-toface courses and although discussions about dropout rates are not addressed in the published papers analyzed, it is noticeable that, in some cases, few participants completed the course, which tend to combine theoretical and practical tasks, due to the hope that the experience would lead to more offerings of subjects taught in English. Not surprisingly, one of the expected outcomes is increased selfconfidence (Martinez \& Fernandes, 2020; Rodrigues \& Rocha, 2020). Further research is needed to understand the high dropout rates. Potential reasons can be associated to different expectations (EMI interpreted as an English course and later realizing it deals with pedagogy) and the fear of exposure to colleagues (as some courses require teaching of a class for the course participants).

In terms of objectives, the courses aimed at preparing teachers to start teaching in EMI share the assumption that the participants had little or no experience in this area. Both language and pedagogical purposes are addressed by these courses within an instrumental view. Except for Verdu (2017) who comes from the Business area, all the other authors work in the TESOL field, and therefore suggest a focus on communication and language, as well as studentcentered teaching techniques common in language teaching. In discussing the competencies for EMI teachers, Macaro et al. (2019, p. 154) ponder that in relation 
to courses offered by external organizations, "we might venture to suggest that there is a heavy emphasis on teachers' general English competence rather than the ability to evaluate where students are linguistically and adapt language and pedagogy accordingly [...] in order to ensure content learning success".

That does not mean that issues about English as a global language do not find space in the courses mentioned here, but they may be treated marginally. If we observe the list of content of those courses, we can notice that some do include issues related to political aspects of teaching in English, but the majority tend to provide tools for teachers. In fact, more critical perspectives on EMI are advocated by authors such as Jordão (2019), Gimenez (2019) and Jordão et al. (2020).

In terms of methodology, in the majority of cases, there was the intention of involving the lecturers as much as possible, making the course interactive, with a final hands-on product with a view to promoting more EMI classes. In the case of state universities in Paraná, the courses were part of an inductive strategy since the convenors explained the initiative in terms of previous commitment to reproduce the experience.

In the case of the course objectives, one might think of a continuum along a matrix that would enable placing the courses along the axes: critical/instrumental; language-focused/pedagogy-focused, as indicated in Table 4. A critical approach would include topics such as the hegemony of English and how it has been constructed, whereas an instrumental view would take it for granted that English 'is' the language of science and would just provide tools for teachers to implement classes disregarding discussions around the ownership of English. On the other hand, courses focusing on language would largely provide guidance on how to deal with linguistic issues and pedagogy-oriented courses would focus on how to teach, i.e., methodology.

Table 4 - Courses foci

\begin{tabular}{|l|l|l|l|l|}
\hline & Critical & Instrumental & Language-focused & Pedagogy-focused \\
\hline UFPI & & & & \\
\hline UEM - A & & & & \\
\hline UEM - B & & & $?$ & $?$ \\
\hline UFPR - A & & & & \\
\hline UFPR - B & & & & \\
\hline UFPR - C & & & & \\
\hline UFPR - D & & & & \\
\hline UNISINOS & & & & \\
\hline
\end{tabular}

Note. Developed by the authors 


\section{Discussion}

Considering that many universities in Brazil reported the offer of EMI courses especially at postgraduate level (Gimenez et al., 2018), it is indeed surprising that so few studies on this initiative are publicly available. Our analysis is just a first step in the attempt to give more visibility to reports on this internationalization strategy. This may call for more research on this booming area considering further developments on EMI teacher education. Areas for further research could include ethnographic studies on teacher education approaches adopted in those courses, impact of the courses on policy and on classroom practices, students' challenges in attending EMI classes; and the relationship between the profile of EMI teacher educators and course design, among others.

Our data reveals that some universities have been more active in documenting and reporting the experience, with more than one publication. One aspect that calls attention is the high dropout rate, but the reports publicly available do not address this issue, which would be another relevant topic for investigation.

In terms of syllabus, there is great diversity, with some items related to language and others to pedagogy. This duality may be the result of the practical implications of a language policy that demands new teaching competencies, i.e. lecturers have to reconstruct their pedagogical content knowledge beyond their own field of expertise. Most of these lecturers have been educated as professionals in their fields, not in pedagogical matters. As EMI teachers, they face new language challenges which also invite new pedagogical practices. In fact, these seem to be the main concerns of lecturers involved in EMI initiatives, with varying degrees of importance.

Additionally, diverse understandings of EMI can be observed in the syllabi presented here, reflecting local constraints, needs, and principles (Pusey, 2020b), even within the same institution. This may be the reflection of the beginning stages of a growing field, and as more experiences are reported and shared, the contours of Brazilian EMI courses may become clearer and perhaps reveal more critical perspectives on this strategy, as indicated by Pusey (2020b) and Jordão (2016), especially if the local knowledge of TESOL professionals is valued: "Having a critical understanding of what EMI entails will help equip teachers with knowledge and strategies to make informed decisions about their teaching, which may ultimately lead to more equitable and enjoyable teaching and learning experiences for all” (Pusey, 2020b, pp. 8).

In relation to the research question 'What are the characteristics of EMI teacher education courses announced by universities in Brazil, in relation to facilitators, target audience, duration and mode of delivery?' our findings reveal a great diversity in the duration of those courses, mostly offered in person, with the help of foreign experts in some cases. The target audience is postgraduate professors, considering the strong introduction of EMI at this level (Gimenez et al., 2018) and the funding schemes that value this practice.

Regarding the second research question 'According to published reports of EMI teacher education courses, who are the participants, what are the objectives, syllabi, 
and methodologies?', we found that the participants were mostly postgraduate professors, who were expected to start teaching in English. Most of the syllabi seemed to follow an instrumental approach with both language and pedagogical purposes. The methodology combined the introduction of some concepts related to language learning and hands-on experience with a demo lesson.

In relation to 'the most explored aspects in the professional development of EMI

lecturers considering those reports and what they indicate', the results suggest the concern with exploring language learning in EMI classes, probably due to the fact that the course delivers were language professionals and the understanding that such a practice demands specialized knowledge to be added to the pedagogical repertoire of content teachers.

Finally, EMI teacher education in Brazil has many research gaps, since this specific field is still in its infancy, as we mentioned before. Follow-up studies with those attending the courses can shed light on their impact on those development areas envisaged by the course convenors, as well as to which designs are better suited to the institutional goals. Likewise, the community of EMI teacher educators can take the task of documenting and sharing experiences, evaluating initiatives and developing practice-based theories that can further feed into future practices.

\section{Concluding remarks}

While in no way was this paper intended to present an overview of EMI teacher education in Brazil, we hope we managed to give visibility to some of the reported experiences, with a view to encouraging more research in this area. One of the limitations in our paper on EMI teacher education courses offered by Brazilian universities is that we drew mainly on what was publicly available, and few publications report on the experience with sufficient detail. Further research may involve in-depth studies within the network of institutions pursuing internationalization goals, such as the ones funded by the CAPES PrInt program.

Through the data presented here, it is possible to identify some relevant aspects/gaps about professional development on EMI. The analysis we made in this article confirms that little is known about preparation courses on EMI for higher education teachers in Brazil. Both quantitative and qualitative studies are needed, and some may be ongoing in postgraduate programs. We hope this text is an invitation to more of these studies be developed and disseminated.

\section{Notes}

1. We suggest further studies and problematization on the term "training" for EMI preparation courses since it can refer to a specific conception of EMI as an English based on a trained use.

2. Dearden (2015) defines EMI as "The use of the English language to teach academic subjects in countries or jurisdictions where the first language (L1) of the majority of the population is not English." (Dearden, 2015, pp. 2). 


\section{References}

Aizawa, I.; Rose, H. (2019). An analysis of Japan's English as medium of instruction initiatives within higher education: the gap between meso-level policy and microlevel practice. Higher Education, 77, 1125-1142.

Baumvol, L. K.; Sarmento, S. (2016). A internacionalização em casa e o uso de inglês como meio de instrução. In: M. S. Beck; M. E. Moritz; M. L. M. Martins; V. Heberle (orgs.), Echoes: Further Reflections on Language and Literature. Florianópolis: UFSC, (pp. 65-82).

Baumvol, L. K.; Sarmento, S. (2019). Can the use of English as a Medium of Instruction promote a more inclusive and equitable higher education in Brazil? Simon Fraser University Educational Review, 12(2), 87-105.

Celani, M. A.; Freire, M. M.; Ramos, R. C. G. (Orgs.). 2009. A abordagem instrumental no Brasil: um projeto, seus percursos e seus desdobramentos. $1^{\text {a }}$ ed., Campinas, Mercado de Letras.

Curle, S.; Yuksel, D.; Soruc, A.; Altay, M. (2020). Predictors of English Medium Instruction academic success: English proficiency versus First language medium. System, 95(1):1-29.

Dearden, J. (2015). English as a medium of instruction: A growing global phenomenon. London: British Council. Available at: https://www.britishcouncil.org/education/ ihe/knowledge\%20centre/english-language-higher-education/report-englishmediuminstruction. Access on: May 28, 2021.

Galloway, N. (2020). English in higher education. English medium Part 1. London, British Council.

Galloway, N.; Rose, H. (2021). English medium instruction and the English language practitioner. ELT Journal, 75(1), 33-41.

Gimenez, T. (2019) Language ideologies and English as a medium of instruction: language policy enactment $\mathrm{n}$ Brazilian universities In: K. Finardi (org) English in the South. (pp.51-74). Londrina: EDUEL.

Gimenez, T.; Sarmento, S.; Archanjo, R.; Zicman, R.; Finardi, K. (2018). Guide to English as a Medium of Instruction in Brazilian Higher Education institutions 2018-2019. Available at: https://faubai.org.br/britishcouncilfaubaiguide2018.pdf. Access on: May 28, 2021.

Gimenez, T.; Simões, L. C.; El Kadri, M. S.; Marson, M. Z.; El Kadri, A. (2021). Por uma agenda de pesquisa sobre inglês como meio de instrução no contexto de ensino superior brasileiro. Trabalhos em Linguística Aplicada, 60(2), 518-534.

Jordão, C. M. (2016). Decolonizing identities: English for internationalization in a Brazilian university. Interfaces Brasil/Canadá, 16(1), 191-209.

Jordão, C. M. (2019). Intelligibility, mimicry and internationalization. In: Murata, K. (ed.). EMI from an ELF perspective. (pp. 32-45). Abingdon, Routledge.

Jordão, C. M.; Figueiredo, E. H. D.; Laufer, G. F.; Frankiw, T. C. (2020). Internacionalização em inglês: sobre esse tal de unstoppable train e de como abordar a sua locomotiva. Revista Ñemitỹrã, 1(2), 30-43.

Knight, J. (2021). Higher education internationalization: concepts, rationales and frameworks. Revista Redalint, 1(1), 65-88.

Macaro, E.; Curle, S.; Pun, J; An, J.; Dearden, J. (2018). A systematic review of English medium instruction in higher education. Cambridge University Press 2017, 51(1), 36-76. 
Macaro, E.; Akincioglu, M.; Han, S. (2019). English medium instruction in higher education: Teacher perspectives on professional development and certification. International Journal of Applied Linguistics, 30(1), 144-157.

Martinez, R. (2016). English as a Medium of Instruction (EMI) in Brazilian higher education: challenges and opportunities. In: Finardi, K. R. (ed.), English in Brazil: views, policies and programs. (pp. 193-228). Londrina, Eduel.

Martinez, R.; Fernandes, K. (2020). Development of a Teacher Training Course for English Medium Instruction for Higher Education Professors in Brazil. In: Sánchez-Pérez, M. M. (org.). Advances in Higher Education and Professional Development. (pp. 125-152). IGI Global.

Pecorari, D.; Malmstrom, H. (2018). At the crossroads of TESOL and English Medium Instruction. TESOL Quarterly, 52(3), 497-515.

Pusey, K. J. (2020a). Lessons Learned Piloting an EMI Support Course at a Southern Brazilian University. Brazilian English Language Teaching Journal BELT, 11(2), 1-11.

Pusey, K. J. (2020b). Addressing conceptual disagreements and representation in EMI teacher education. REGIT, 14(2), 102-114.

Rios, E.S.; Calvo, L.C.S., Novelli, J. (orgs) (2021) Paraná Fala Idiomas-Inglês: pesquisas, práticas e desafios de uma política linguística de Estado. Curitiba: SETI.

Rodrigues, B. G.; Rocha, A. O. (2020). Reflecting about the challenge of using English as a Medium of Instruction in Piaui. In: C. L. Richter; D. G. Nóbrega; F. A. M. Souza; J. F. Nascimento (orgs.), Language teaching-learning in the 21st century. (pp. 119-128) São Paulo, Mentes Abertas.

Sarmento, S.; Abreu-e-Lima, D.; Moraes Filho, W. (orgs) (2016) Do inglês sem fronteiras ao Idiomas sem Fronteiras. Belo Horizonte: Editora UFMG.

Schreier, M. (2012). Qualitative content analysis in practice. Sage publications.

Verdu, F. C. (2017). EMI (English as a Medium of Instruction) como estratégia de internacionalização em casa: um estudo de caso num programa de pós-graduação em administração. São Paulo. Anais do EnANPAD 2017, São Paulo, SP. p. 1-8.

Wilkinson, R.; Gabriëls, R. (eds) (2021). The Englishization of higher education in Europe. Amsterdam: Amsterdam University Press.

Züge, A.; Barreto, A.; Novelli, J. (2020). EMI em foco: percepções, possibilidades e desafios. Revista NUPEM, 12(26), 43-61.

Recebido em: 25/06/2021 Aceito em: 25/11/2021 